\title{
Por uma ordo amoris \\ Reflexões alvesianas sobre a libertação humana
}

\author{
Orientador: Abimar Oliveira de Moraes \\ Mestrando: Rainerson Israel Estevam de Luiz \\ Área de Concentração: Teologia Sistemático-Pastoral
}

Linha de Pesquisa: Fé e Cultura

O propósito dessa pesquisa foi refletir sobre a teologia de Rubem Alves. Nesta pesquisa foi analisada especificamente a primeira fase do pensamento de Rubem Alves, a saber, sua proposta de libertação humana. Para além de um protestantismo passivo diante da injusta realidade, o autor estudado, absorvendo toda consciência crítica ocidental, fez nascer em solos latino-americanos uma proposta de libertação humana de todas as estruturas que impossibilitam a vida. O ser humano, na teologia de Rubem Alves, é pensado enquanto homo creator. Se a linguagem do tecnologismo ou a linguagem eclesiástica domesticam as ações humanas, tornando-as meras réplicas do que já está, Alves denuncia os "acordos silenciosos" das mesmas e anuncia o ser humano livre para $o$ ato criativo. Esta pesquisa propõe analisar a primeira fase do pensamento de Alves sob dois momentos, a saber, o dialético-político e o estético-imaginativo. No primeiro momento é abordado o messianismo humanista (expressão alvesiana) que a partir de uma plataforma sociológica (humanismo político) propõe uma libertação dialética e política. No segundo momento é tratada a libertação humana a partir de elementos heterodoxos tais como a magia, a experiência lúdica, o corpo e a imaginação. E assim o trabalho mostra que esses dois momentos da primeira fase do pensamento de Alves foram extremamente frutíferos e vanguardistas para a teologia latino-americana.

Palavras-chave: Política; Dialética; Libertação; Corporeidade; Imaginação; Magia; Lúdico; Linguagem; Comunidade; Rubem Alves. 